\title{
HASIL BELAJAR BOLA BASKET DENGAN PENERAPAN MODEL PEMBELAJARAN KOOPERATIF TIPE STAD
}

\author{
Oleh \\ Kadek Arya Dwi Antara, I Made Danu Budhiarta, Made Agus \\ Wijaya \\ Jurusan Pendidikan Jasmani Kesehatan dan Rekreasi \\ Fakultas Olahraga dan Kesehatan, Universitas Pendidikan Ganesha, \\ Kampus Tengah Undiksha Singaraja, Jalan Udayana Singaraja-Bali Tlp. (0362) 32559 \\ e-mail:aryadwiantara0604@gmail.com,danu tantri@yahoo.co.id, \\ wijaya.madeagus@undiksha.ac.id
}

\begin{abstract}
Abstrak
Penelitian ini bertujuan mengetahui pengaruh model pembelajaran kooperatif tipe Student Teams Achievement (STAD) terhadap hasil belajar teknik dasar passing bola basket (passing overhead pass dan passing chest pass). Penelitian merupakan penelitian eksperimen sungguhan (true experimental) dengan menggunakan rancangan penelitian the pretest post-test control group design. Penelitian dilaksanakan pada siswa kelas XI SMA Karya Wisata Singaraja tahun pelajaran 2016/2017 dengan sampel berjumlah 46 orang siswa yang terdistribusi ke dalam dua kelas yaitu kelas XI IPB 5 dan kelas XI IPB 6. Teknik sampling menggunakan simple random sampling. Data hasil belajar terdiri atas 1) aspek kognitif, menggunakan tes essay, 2) aspek afektif, menggunakan observasi sikap siswa selama pembelajaran, dan 3) aspek psikomotor, menggunakan observasi kinerja passing bola basket. Tahapan analisa data terdiri atas: 1) uji prasyarat, menggunakan uji normalitas data menggunakan Kolmogorov-Smirnov dan uji homegenitas Levene's Test of Equality of Error Variance, serta 2) Uji hipotesis, menggunakan uji-t pada taraf signifikansi $p<0.05$.Berdasarkan uji prasyarat, di peroleh hasil bahwa data penelitian berdistribusi normal dan homogen.Uji-t menunjukkan $t_{\text {hitung }} 2.430$ sedangkan $t_{\text {tabel }}$ sebesar 1.678 dan nilai signifikansi yang diperoleh melalui uji $\mathrm{t}$ adalah 0,019. Merujuk hasil analisa data dan pembahasan, simpulan penelitian ini adalah penerapan model pembelajaran kooperatif tipe STAD berpengaruh signifikan terhadap peningkatan hasil belajar teknik dasar passing bola basket pada siswa kelas XI SMA Karya Wisata Singaraja tahun pelajaran 2016/2017. Dengan demikian disarankan kepada guru penjasorkes dapat menerapkan model pembelajaran kooperatif tipe STAD karena terbukti berpengaruh signifikan terhadap peningkatan hasil belajarsiswa.
\end{abstract}

Kata-kata kunci : :Kooperatif, STAD, hasil belajar, bola basket

\begin{abstract}
This study aimed to determine the effect of cooperative learning model of Student Teams Achievement Devision (STAD) type trough result of learning on basic technique of passing basketball (passing overhead pass and passing chest pass). The study was a real experimental study using the pretest post-test control group design. The experiment was conducted on students of class XI High School Karya Wisata Singaraja academic year 2016/2017 with a sample of 46 students were distributed into two classes, namely class XI IPB 5 and XI IPB 6. Simple random sampling was used in this study. Data from study consisted of; 1) cognitive, use essay tests, 2) affective, using observation attitudes of the students during learning, and 3) psychomotor aspects, using the observation of the of
\end{abstract}


passing performance basketball. Data analysis stages; 1) prerequisites test, test data normality using the Kolmogorov-Smirnov test homegenitas Levene's Test of Equality of Error Variance, and 2) test the hypothesis, using t-test at a significance level of $p<0.05$. Based prerequisite test, the obtained results of the study data were normally distributed and homogen. $t$-test show $t 2.430$ while ttable 1,678 and significance values obtained through $t$ - test was 0,019. Show the data analysis and discussion, conclusion of this study is the implementation of cooperative learning model STAD effect Significant to the improvement learning result on basic technique of passing basketball at class XI students of High School Karya Wisata Singaraja academic year 2016/2017. Thus, it is suggested to the teacher of physical education sports and health to apply STAD type cooperative learning model because it proved to have a significant effect on the increase of learning result.

keywords; cooperative, STAD, learning result, basketball

\section{PENDAHULUAN}

Pendidikan jasmani merupakan bagian integral dari sistem pendidikan secara keseluruhan. Oleh karena itu, pelaksanaan pendidikan jasmani harus diarahkan pada pencapaian tujuan pendidikan tersebut. Tujuan pendidikan jasmani bukan aktivitas jasmani itu sendiri, tetapi untuk mengembangkan potensi siswa melalui aktivitas jasmani. Persepsi yang sempit dan keliru terhadap pendidikan jasmani akan mengakibatkan nilai-nilai luhur dan tujuan pendidikan yang terkandung di dalamnya tidak akan pernah tercapai. Orientasi pembelajaran harus disesuaikan, dengan perkembangan anak, isi dan urusan materi serta cara penyampaian harus disesuaikan sehingga menarik dan menyenangkan, sasaran pembelajaran ditujukan bukan hanya mengembangkan keterampilan olahraga, tetapi perkembangan pribadi anak seutuhnya. Konsep dasar pendidikan jasmani dan model pengajaran pendidikan jasmani yang efektif perlu dipahami bagi orang yang hendak mengajar pendidikan jasmani.

Kebanyakan para Guru penjasorkes memberikan materi kepada siswa hanya sebatas peragaan contoh gerakan kemudian akan dilakukan evaluasinya setelah proses pembelajaran akan selesai, disini siswa tidak akan mudah untuk memahami dimana letak kesalahan dan kekurangan mereka. Sehingga siswa kurang merespon dari setiap materi yang dijelaskan kepada mereka. Kurangnya motivasi belajar dapat mempengaruhi ketertarikan siswa untuk

mengikuti aktivitas pembelajaran seharihari. Permasalahan-permasalahan tersebut kebanyakan karena guru tidak melakukan variasi pembelajaran dan memanfaatkan sarana pembelajaran yang ada untuk dijadikan bahan bantuan untuk menyampaikan materi pelajaran serta menggunkan model pembelajaran inovatif. Sehubungan dengan hal tersebut peneliti tertarik untuk memecahkan masalah tersebut dengan melakukan penelitian menggunakan model pembelajaran inovatif. Salah satu model tersebut adalah pembelajaran kooperatif.

Disamping itu, pembelajaran penjasorkes di SMA Karya Wisata Singaraja kurang efektif karena model pembelajaran yang digunakan bersifat monoton serta kurang memperhatikan kemampuan individu siswa, padahal kemampuan setiap individu siswa belum tentu sama. SMA Karya Wisata Singaraja adalah sekolah yang memiliki siswa dengan latar belakang yang berbeda-beda yaitu latar belakang sosial, tingkat prestasi dan kemampuan setiap individu. Sehingga memerlukan inovasi pembelajaran yang sesuai, agar hasil pembelajaran penjasorkes dapat berjalan sesuai dengan tujuan. Untuk itu diberikan inovasi pembelajaran yang sesuai dengan latar belakang tersebut.

Selain itu, pemilihan tentang model pembelajaran STAD ini juga dikuatkan oleh hasil penelitian dari peneliti-peneliti sebelumnya, antara lain: (1) Sudiarpa 
(2015) menyatakan bahwa hasil penelitian menunjukan bahwa secara keseluruhan rata-rata skor hasil belajar IPA siswa pada kelompok eksperimen yaitu sebesar 13,69 lebih tinggi dibandingkan dengan rata-rata skor hasil belajar siswa pada kelompok kontrol yaitu 11,73 . Dengan demikian nilai rata-rata kelompok eksperimen lebih dari pada nilai rata-rata kelompok kontrol. (2) Diperkuat oleh Sariyasa (2013) menunjukkan bahwa hasil belajar siswa yang mengikuti pembelajaran dengan model pembelajaran kooperatif tipe STAD lebih baik daripada siswa yang mengikuti model pembelajaran konvensional, keterampilan sosial pada siswa yang mengikuti pembelajaran dengan model pembelajaran kooperatif tipe STAD lebih baik daripada siswa yang mengikuti model pembelajaran konvensional, dan hasil belajar dan keterampilan sosial siswa yang mengikuti model pembelajaran kooperatif tipe STAD lebih baik daripada model pembelajaran konvensional.

Berdasarkan uraian di atas peneliti tertarik untuk mengadakan penelitian dengan judul "Pengaruh Penerapan Model Pembelajaran Kooperatif Tipe Student Teams Achievement Division (STAD) Terhadap Hasil Belajar Teknik Dasar Passing Bola Basket Pada Siswa Kelas XI IPB SMA Karya Wisata Singaraja"

Menurut Slavin (2005: 4), "Cooperative Learning atau pembelajaran kooperatif sebagai salah satu model pembelajaran yang menyenangkan dan siswa akan lebih paham." Pembelajaran kooperatif memungkinkan siswa belajar dengan berkelompok untuk saling berdiskusi dan bersaing. Pembelajaran kooperatif menjadikan siswa lebih aktif dalam belajar. Ada banyak jenis dari pembelajaran kooperatif dan salah satunya adalah Student Team Achievement Division (STAD). "Model pembelajaran kooperatif tipe STAD merupakan salah satu model pembelajaran kooperatif yang paling sederhana, dan model yang paling baik bagi para guru yang baru menggunakan pendekatan kooperatif" (Slavin,2005: 4). Model pembelajaran kooperatif tipe STAD adalah salah satu pendekatan pembelajaran yang menekankan keterlibatan siswa secara penuh dalam kelompok, dan siswa sebagai subyek belajar yang mana berperan aktif disetiap proses pembelajaran. Dalam pembelajaran kooperatif tipe STAD merupakan salah satu tipe dari model pembelajaran kooperatif dengan menggunakan kelompok-kelompok kecil dengan jumlah anggota tiap kelompok 4-5 orang yang merupakan campuran menurut tingkat prestasi, jenis kelamin dan suku. Diawali dengan penyampaian tujuan pembelajaran, penyampaian materi, kegiatan kelompok, kuis, dan penghargaan kelompok.

Dari hasil penelitian tersebut menunjukan bahwa model pembelajaran kooperatif tipe STAD meningkatkan hasil belajar peserta didik dalam melakukan teknik dasar passing dengan overhead pass dan chest pass bola basket. Maka peneliti mencoba melakukan penelitian menggunakan model pembelajaran kooperatif tipe STAD . Dari model tersebut peneliti ingin mengetahui apakah ada pengaruh penerapan model tersebut terhadap hasil belajar passing dengan overhead pass dan chest pass bola basket.

Pembelajaran merupakan upaya yang sistematik dan disengaja oleh pendidik untuk menciptakan kondisikondisi agar peserta didik melakukan kegiatan belajar. "Pembelajaran merupakan suatu kombinasi yang tersusun meliputi unsur-unsur manusiawi, material, fasilitas, perlengkapan, dan prosedur yang saling mempengaruhi untuk mencapai tujuan pembelajaran" (Hamalik, 2008:57). Pembelajaran dapat diartikan sebagai suatu upaya untuk menciptakan kondisi yang memungkinkan siswa dapat belajar. Menurut Dimyati \& Mudjiono, (2006:231) "pembelajaran memuat titik interaksi, antara pembelajar dan pelajar berorientasi pada sasaran belajar, berakhir dengan evaluasi". Kegiatan pembelajaran dirancang untuk memberikan pengalaman belajar yang melibatkan proses mental dan fisik melalui interaksi antara peserta didik, peserta didik dengan guru, lingkungan, dan sumber belajar lainnya dalam rangka pencapaian kompetensi dasar. 
Berdasarkan pendapat tersebut di atas maka dapat disimpulkan bahwa, pembelajaran adalah suatu proses perubahan dan pengembangan tingkah laku sebagai hasil interaksi pengetahuan keterampilan atau sikap pada saat individu berinteraksi dengan informasi dan lingkungan dalam memenuhi kebutuhan hidupnya.

Belajar dan mengajar merupakan dua konsep yang tidak dapat dipisahkan satu sama lain dalam proses pembelajaran. Pengertian belajar dapat kita temukan di berbagai sumber atau literatur. Sumantri \& Permana (dalam Sudiana, 2006:5) menjelaskan pengertian belajar secara tradisional dan modern. Secara tradisional, belajar diartikan sebagai upaya menambah dan mengumpulkan sejumlah pengetahuan. Sedangkan secara modern, belajar diartikan sebagai setiap perubahan tingkah laku yang relatif tetap dan terjadi sebagai hasil latihan dan pengalaman. Belajar juga merupakan perubahan yang relatif permanen yang terjadi dalam kecenderungan perilaku dan praktek yang dilakukan. Jadi substansi belajar adalah perubahan perilaku. Sedangkan menurut Slameto (2003:2), "belajar adalah suatu proses usaha yang dilakukan seseorang untuk memperoleh suatu perubahan karakter yang baru secara keseluruhan, sebagai hasil pengalaman dari interaksi dengan lingkungannya".

Dari pendapat di atas dapat disimpulkan, belajar merupakan suatu proses kegiatan aktif dan dilakukan secara sadar yang ditunjukkan dengan timbulnya perubahan prilaku secara permanen atau tetap berdasarkan pengalaman yang bersifat positif yang meliputi perubahan cara berpikir (kognitif), tingkah laku (afektif), dan gerak (psikomotor) yang akan terjadi seumur hidup.

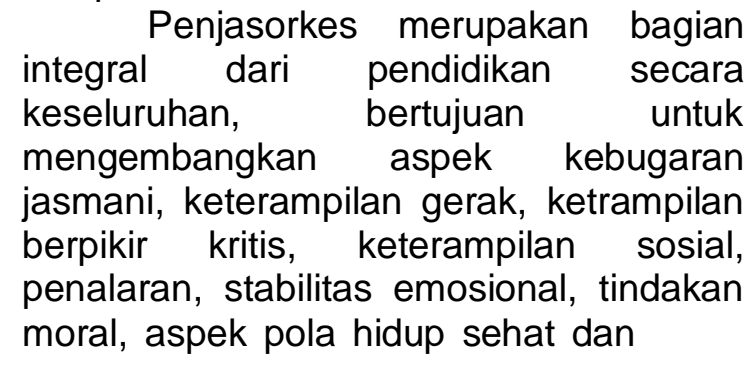

pengenalan lingkungan bersih melalui aktivitas jasmani, olahraga, dan kesehatan terpilih yang direncanakan secara sistematis dalam rangka mencapai tujuan pendidikan nasional.

Suherman, (2000:1) mengatakan "penjasorkes pada dasarnya merupakan pendidikan melalui aktivitas jasmani yang dijadikan sebagai media untuk mencapai perkembangan individu secara menyeluruh". Penjasorkes adalah satu aspek dari proses pendidikan keseluruhan yang berkenaan dengan perkembangan dan penggunaan kemampuan gerak individu yang sukarela dan berguna, serta berhubungan langsung dengan respon mental, emosional, dan sosial. Penjasorkes merupakan pendidikan melalui aktivitas jasmani yang dijadikan sebagai media untuk mencapai perkembangan individu secara menyeluruh. Namun perolehan keterampilan dan perkembangan lain yang bersifat jasmaniah itu juga sekaligus sebagai tujuan. Melalui Penjasorkes, siswa disosialisasikan ke dalam aktivitas jasmani termasuk keterampilan berolahraga. Yamamoto (dalam Dimyati dan Mudjiono, 2006:119) mengungkapkan bahwa "proses pembelajaran yang optimal terjadi apabila siswa yang belajar maupun guru yang membelajarkan memiliki kesadaran dan kesengajaan terlibat dalam proses pembelajaran". Pendidikan sebagai suatu proses pembinaan manusia yang berlangsung seumur hidup, Penjasorkes yang diajarkan di satuan pendidikan nonformal penyelenggara pendidikan kesetaraan memiliki peranan sangat penting, yaitu memberikan kesempatan kepada peserta didik untuk terlibat langsung dalam berbagai pengalaman belajar melalui aktivitas jasmani, olahraga dan kesehatan yang terpilih yang dilakukan secara sistematis.

Dari pendapat di atas, maka yang dimaksud dengan pembelajaran dalam penjasorkes adalah suatu kombinasi yang tersusun atas unsur-unsur manusia, material, fasilitas dan prosedur yang saling mempengaruhi untuk mencapai tujuan mengembangkan kebugaran fisik, mental, emosi, dan sosial masyrakat melalui media aktivitas fisik. 
Hasil belajar adalah hasil tertinggi yang diperoleh dari proses pembelajaran yang berupa perubahan sikap dan penampilan dari individu dengan cara mengamati, menirukan, mencoba dan mendengarkan petunjuk serta pengarahannya. Proses penilaian terhadap hasil belajar dapat memberikan informasi kepada guru tentang kemajuan siswa dalam upaya mencapai tujuantujuan belajarnya melalui kegiatan belajar.

Penilaian dilakukan secara konsisten, sistematik, dan terprogam dengan menggunakan tes dan notes dalam bentuk tertulis atau lisan, pengamatan kinerja, pengukuran sikap, penilaian hasil karya berupa tugas, proyek dan/atau produk, portofolio, dan penilaian diri. Penilaian hasil pembeajaran mengguakan standar penilaian pendidikan dan panduan penilaian kelompok mata pelajaran.

Hasil belajar adalah hasil siswa dalam proses pembelajaran. Hasil belajar adalah kemampuan yang diperoleh seseorang dari suatu interaksi dalam proses pembelajaran. "Hasil belajar merupakan hasil dari suatu interaksi tindak belajar dan tindak mengajar" (Dimyati dan Mudjiono, 2006:3). Hasil belajar tersebut dapat dibedakan menjadi dampak pengajaran dan dampak pengiring. Dampak "pengajaran adalah hasil yang dapat di ukur seperti yang tertuang dalam angka raport, angka ijazah atau kemampuan meloncat setelah latihan. Sedangkan dampak pengiring adalah terapan pengetahuan dan kemampuan di bidang lain suatu transfer belajar" (Dimyati dan Mudjiono,2006:4).

\section{METODE PENELITIAN}

Jenis penelitian yang digunakan dalam penelitian ini adalah eksperimen sesungguhnya (true experimental). "jadi cirinya adalah adanya kelompok kontrol dan sampel dipilih secara random" (Sugiyono, 2012: 112).

"Tujuan dari penelitian eksperimen sungguhan adalah untuk menyelidiki kemungkinan saling hubungan sebabakibat dengan cara mengenakan kepada satu atau lebih kelompok eksperimental satu atau lebih kondisi perlakuan dan memperbandingkan hasilnya dengan satu atau lebih kelompok kontrol yang tidak dikenai kondisi perlakuan"(Kanca, 2010:86).

Rancangan pada penelitian ini
adalah rancangan the randomized pretests-postest control group the same subjec design.

\section{HASIL dan PEMBAHASAN}

Tabel 4.1

Rangkuman Data Hasil Belajar Passing Bola basket

\begin{tabular}{lcc}
\hline Variabel & Kelompok Eksperimen & Kelompok Kontrol \\
\hline Banyak Siswa (N) & 23 & 23 \\
Rata-rata Pretest & 73,174 & 74,043 \\
Standar Deviasi (SD)pretest & 7,9295 & 8,2433 \\
Rata-rata posttest & 82,739 & 76,870 \\
Standar Deviasi (SD)posttest & 8,3623 & 8,0188
\end{tabular}


Data tentang hasil belajar teknik dasar passing bola basket (chest pass dan overhead pass) diperoleh melalui tes akhir (post test) yang ditunjukkan pada lampiran 25. Penelitian ini dilaksanakan dari tanggal 25 April sampai dengan tanggal 26 Mei 2017 dengan empat kali pertemuan pada masing-masing kelompok. Pertemuan pertama merupakan pengambilan nilai tes awal (pretest) siswa, Pada kelompok eksperimen dilakukan pada Selasa,16 Mei 2017 sedangkan pada kelompok kontrol dilakukan pada Kamis, 19 Mei 2017. Kemudian pertemuan kedua dan ketiga adalah pemberian perlakuan pada masing-masing kelompok dimana kelompok eksperimen diberikan perlakuan berupa model pembelajaran kooperatif tipe STAD dan pada kelompok kontrol diberikan perlakuan berupa model pembelajaran koperatif tipe konvensional. Pemberian perlakuan pada kelompok eksperimen dilakukan pada Jumat, 19 Mei 2017 dan 20 Mei 2017, sedangkan pada kelompok kontrol dilakukan pada Rabu,22 Mei 2017 dan 23 Mei 2017. Pertemuan keempat adalah pengambilan nilai tes akhir (posttest). Pada kelompok

eksperimen dilakukan pada Selasa, 24 Mei

2017 dan kelompok kontrol Rabu, pada 25 Mei 2017.Perlakuan pada kedua kelompok dilakukan pada Selasa, 25 April 2017 dan 26 Mei 2017. Rangkuman analisis terhadap data hasil belajar teknik dasar passing bola basket pada kelompok eksperimen dan kelompok kontrol seperti tercantum pada Tabel 4.1berikut.

Berdasarkan Tabel 4.1 Tentang hasil posttest diperoleh rata-rata skor kelompok eksperimen $=82,739$ sedangkan rata-rata skor kelompok kontrol $=76,870$. Standar deviasi dari kelompok eksperimen $=8,3623$ sedangkan standar deviasi Pengujian normalitas sebaran data dilakukan untuk meyakinkan bahwa subjek penelitian berdistribusi normal. Untuk mengetahui normalitas sebaran data digunakan rumus KolmogorovSmirnov pada signifikansi 0,05 . Jika $p>$ 0,05 data berdistribusi normal, sebaliknya jika $p<0,05$ data tidak berdistribusi normal. Berdasarkan analisis yang telah dilakukan dengan menggunakan SPSS 16.00 for Windows iasi dari kelompok kontrol $=8,0188$. , terlihat bahwa untuk semua variabel signifikansi pada uji Kolmogorov-Smirnov lebih besar dari 0,05 . Dengan demikan maka semua sebaran data berdistribusi normal.

\section{Tabel 4.2}

\section{Hasil Uji Normalitas Sebaran Data}

\begin{tabular}{ccccc}
\hline & Kelas & \multicolumn{3}{c}{ Kolmogorov-Smirnova } \\
& & Statistic & df & Sig. \\
nilai & nilai kelas XI IPB & .143 & 23 & $.200^{*}$ \\
$\begin{array}{c}\text { akhir } \\
\end{array}$ & $\begin{array}{c}\text { nilai kelas XI IPB } \\
6\end{array}$ & .174 & 23 & .070 \\
\hline
\end{tabular}

Pengujian normalitas sebaran data dilakukan untuk meyakinkan bahwa subjek penelitian berdistribusi normal. Untuk mengetahui normalitas sebaran data digunakan rumus KolmogorovSmirnov pada signifikansi 0,05. Jika p>
0,05 data berdistribusi normal, sebaliknya jika $p<0,05$ data tidak berdistribusi normal. Berdasarkan analisis yang telah dilakukan dengan menggunakan SPSS 16.00 for Windows didapatkan hasil seperti Tabel 4.2 berikut. 
Tabel 4.3

Rangkuman Hasil Uji Homogenitas Varians menggunakan Levene's Test of Equality of Error Variances ${ }^{a}$

\begin{tabular}{|c|c|c|c|}
\hline $\begin{array}{l}\text { Levene } \\
\text { Statistic }\end{array}$ & df1 & $\mathrm{df2}$ & Sig. \\
\hline .014 & 1 & 44 & .907 \\
\hline
\end{tabular}

Uji homogenitas varian dilakukan dengan pengelompokan berdasarkan model pembelajaran, yaitu model pembelajaran kooperatif tipe Teams Achievement (STAD)dengan model pembelajaran konvensional. Uji homogenitas varians antar kelompok dilakukan dengan bantuan SPSS 16.00 for Windows dengan menggunakan Levene's Test Of Equality Error Variance. Hipotesis statistik yang diuji dalam pengujianhomogenitas adalah sebagai berikut.

$H_{0}$ : variansi pada setiap kelompok adalah sama (homogen) $H_{a}$ : variansi pada setiap kelompok tidak sama (tidak homogen)

Dengan kriteria pengujian yang digunakan adalah terima $H_{0}$ jika nilai $p>$ 0,05 dimana data memiliki varians yang sama apabila angka signifikansi yang dihasilkan lebih dari 0,05. Rangkuman hasil perhitungan homogenitas data menggunakan SPSS 16.00 for Windows.

hasil uji Levene's menunjukkan bahwa untuk hasil belajar teknik dasar passing bola basket siswa taraf signifikansi 0,907. Bila ditetapkan taraf signifikansi 0,05 maka hasil uji homogenitas varians tidak signifikan karena lebih besar dari taraf signifikansi yang ditetapkan, sehingga dapat disimpulkan bahwa variansi pada setiap kelompok adalah sama (homogen). Berdasarkan Tabel 4.3, hasil uji Levene's menunjukkan bahwa untuk hasil belajar teknik dasar passing bola basket siswa taraf signifikansi 0,907. Bila ditetapkan taraf signifikansi 0,05 maka hasil uji homogenitas varians tidak signifikan karena lebih besar dari taraf signifikansi yang ditetapkan, sehingga dapat disimpulkan bahwa variansi pada setiap kelompok adalah sama (homogen).

Tabel 4.4

Ringkasan Analisis Uji-t Dengan Menggunakan SPSS

\begin{tabular}{|c|c|c|c|c|c|c|c|c|c|}
\hline & & $\begin{array}{l}\text { Lev } \\
\text { Tes } \\
\text { Equa } \\
\text { Vari }\end{array}$ & $\begin{array}{l}\text { ne's } \\
\text { t for } \\
\text { lity of } \\
\text { nces }\end{array}$ & & & t-test fo & r Equal & ity of $\mathrm{Me}$ & ans \\
\hline & & $\mathrm{F}$ & Sig. & $\mathrm{t}$ & df & $\begin{array}{c}\text { Sig. } \\
(2- \\
\text { tailed } \\
\quad)\end{array}$ & $\begin{array}{l}\text { Mean } \\
\text { Differ } \\
\text { ence }\end{array}$ & $\begin{array}{l}\text { Std. } \\
\text { Error } \\
\text { Differ } \\
\text { ence }\end{array}$ & $\begin{array}{l}95 \% \\
\text { Confidence } \\
\text { Interval of the } \\
\text { Difference } \\
\text { Lower Upper }\end{array}$ \\
\hline $\begin{array}{l}\text { nilai } \\
\text { akhir }\end{array}$ & $\begin{array}{l}\text { Equal } \\
\text { variances } \\
\text { assumed }\end{array}$ & $\begin{array}{r}.01 \\
4\end{array}$ & .907 & $\begin{array}{r}2.4 \\
30\end{array}$ & 44 & .019 & $\begin{array}{r}5.869 \\
6\end{array}$ & $\begin{array}{r}2.415 \\
8\end{array}$ & $\begin{array}{rr}1.000 & 10.73 \\
9 & 83\end{array}$ \\
\hline
\end{tabular}




\begin{tabular}{lrrrrrrr} 
Equal & & & & & & & \\
variances & 2.4 & 43. & .019 & 5.869 & 2.415 & 1.000 & 10.73 \\
not & 30 & 923 & & 6 & 8 & 6 & 85 \\
assumed & & & & & & & \\
\hline
\end{tabular}

Hipotesis penelitian yang telah dikemukakan dalam kajian pustaka menyatakan bahwa terdapat perbedaan hasil belajar teknik dasar passing bola basket pada siswa yang diajarkan menggunakan model pembelajaran kooperatif tipe STAD dengan siswa yang dibelajarkan menggunakan model pembelajaran konvensional. Pengujian hipotesis menggunakan uji $t$ dengan bantuan SPSS 16.00 for Windows Hasil analisis dengan uji t disajikan pada Tabel 4.4 berikut ini. Dari perhitungan pada table kerja di atas, diperoleh $t$ hitung 2.430 .

Adapun nilai $t_{\text {tabel }}$ dengan taraf signifikan 0,05 dan derajat kebebasan $\mathrm{dk}=23+23-2$ $=44$ adalah 1.678. Dengan demikian nilai

$t_{\text {hitung }}>t_{\text {tabel }}$ dan nilai signifikan $0,019<$ 0,05 . Adapun keputusan yang diambil adalah tolak $H_{o}$ dan terima $H_{a}$. Hasil ini menyatakan bahwa terdapat perbedaan hasil belajar passing bola basket antara siswa yang diberikan pembelajaran menggunakan model pembelajaran kooperatif tipe STAD dengan siswa yang dibelajarkan menggunakan model pembelajaran konvensional. Berdasarkan angka yang terlihat bahwa rata-rata peningkatan hasil belajar pada kelompok eksperimen lebih besar daripada kelompok kontrol. Dapat disimpulkan bahwa hasil belajar pada siswa yang dibelajarkan menggunakan model pembelajaran kooperatif tipe STAD lebih tinggi daripada siswa yang dibelajarkan menggunakan model pembelajaran konvensional.

Berdasarkan hasil penelitian diperoleh bahwa terdapat perbedaan hasil belajar teknik dasar Passingbola basket siswa yang dibelajarkan dengan model pembelajaran kooperatif tipe STAD pembelajaran dengan siswa yang dibelajarkan dengan model pembelajaran konvensional, ini berarti model pembelajaran kooperatif tipe STAD pembelajaran berpengaruh terhadap hasil belajar teknik dasar Passingbola basket siswa.

Dalam penelitian ini masing-masing kelompok penelitian diberikan perlakuan yang berbeda, dimana kelompok eksperimen diberikan perlakuan berupa model pembelajaran kooperatif tipe STAD pembelajaran sedangkan pada kelompok kontrol diberikan perlakuan model pembelajaran konvensional.STAD adalah salah satu tipe pembelajaran kooperatif yang menempatkan siswa dalam kelompok-kelompok belajar yang beranggotakan 4 sampai 5 orang yang memiliki kemampuan, jenis kelamin dan suku kata atau ras yang berbeda. Guru menyajikan materi, dan siswa bekerja dalam kelompok mereka masing-masing. Apabila ada dari anggota kelompok yang tidak mengerti dengan tugas yang diberikan, maka anggota kelompok yang lain bertanggung jawab untuk memberikan jawaban atau menjelaskannya, sebelum mengajukan pertanyaan tersebut kepada guru.

Berdasarkan pengamatan peneliti pada saat pembelajaran berlangsung di kelompok eksperimen, pembelajaran diarahkan untuk memberikan perhatian terhadap pemahaman siswa tentang teknik dasar passing bola basket di dalam mengikuti pelajaran.Aktivitas siswa yang lebih positif dalam menerima dan memahami materi suatu pelajaran pada kegiatan belajar menjadi salah satu faktor yang membuat rata-rata skor yang diperoleh siswa pada kelompok eksperimen lebih besar daripada rata-rata skor yang diperoleh siswa pada kelompok kontrol.

Pembelajaran yang dilaksanakan di kelompok kontrol dilaksanakan dengan menerapkan model pembelajaran konvensional.Pembelajaran di kelompok kontrol dilakukan dengan model ceramah oleh guru dalam penyampaian materi kemudian mendemonstrasikan materi pelajaran dan menugaskan siswa untuk mempraktikkan materi yang 
diajarkan.Melalui penugasan tersebut diharapkan siswa mampu memahami dan melakukan gerakan dengan benar.

Berdasarkan pengamatan peneliti pada saat pembelajaran berlangsung, model konvensional yang diterapkan di kelompok kontrol pada dasarnya telah menuntun siswa untuk dapat memahami dan mempraktikan gerakan dengan benar. Namun dengan penggunaan model ceramah dalam penyampaian materi pelajaran menyebabkan pembelajaran berpusat pada guru dan masih banyak siswa yang kurang aktif. $\mathrm{Hal}$ ini mengakibatkan kurangya partisipasi siwa secara menyeluruh dalam proses belajar mengajar atau hanya siswa yang memiliki kemampuan lebih saja yang mau aktif dalam proses pembelajaran, sehingga pemahaman dan keterampilan siswa dalam melakukan teknik dasar passing bola basket menjadi terhambat dan tidak merata. Hal ini berbeda dengan pembelajaran pada kelompok eksperimen dengan menggunakan model pembelajaran kooperatif tipe STAD dimana siswa akan banyak mendapatkan waktu belajar dalam kelompok-kelompok yang diatur oleh guru, dan mendapatkan beberapa permainan yang berkaitan dengan materi yang diajarkan. Dan pada penhujung pembelajaran akan diberikan suatu pertandingan antar kelompok yang dimana setiap kelompok akan berlomba mendapatkan nilai yang terbaik.Faktorfaktor tersebutlah yang mengakibatkan pembelajaran yang berlangsung di kelompok eksperimen mendapat respon yang lebih baik dari siswa sehingga ratarata skor siswa di kelompok eksperimen lebih tinggi dari pada rata-rata skor siswa pada kelompok control.

Uraian diatas memberikan gambaran bahwa model pembelajaran kooperatif tipe STAD pembelajaran dalam pembelajaran teknik dasar passing bola basket berpengaruh positif terhadap hasil belajar siswa. Hasil penelitian ini memberikan implikasi bahwa terdapat perbedaan hasil belajar teknik dasar passing bola basket siswa yang diajarkan menggunakan model pembelajaran kooperatif tipe STAD pembelajaran dengan siswa yang dibelajarkan dengan menggunakan model pembelajaran konvensional.

Hasil penelitian telah menunjukkan bahwa hasil belajar passing bola basket (chest pass dan overhead pass) pada kelompok perlakuan yang diberikan model pembelajaran kooperatif tipe STAD lebih tinggi dibandingkan dengan kelompok control yang diberikan model pembelajaran konvensional. Keberhasilan dalam proses pembelajaran tersebut sangat tergantung pada kemampuan guru untuk memilih model pembelajaran kooperatif salah satunya adalah pembelajaran kooperatif tipe STAD, disamping itu guru harus menyesuaikan model pembelajaran dengan karakteristik peserta didik. Oleh karena itu hasil penelitian ini dapat berimplikasi pada beberapa hal sebagai berikut.

Pertama, hasil penelitian ini menunjukkan bahwa hasil belajar passing bola basket pada kelompok perlakuan yang diberikan model pembelajaran kooperatif tipe STAD secara signifikan lebih tinggi dari pada kelompok kontrol yang diberikan model pembelajaran konvensional. Berdasarkan temuan ini, maka untuk meningkatkan kualitas dan hasil belajar passing bola basket dapat dilakukan dengan menerapkan model pembelajaran kooperatif tipe STAD. Implikasi dari hasil penelitian ini adalah penerapan model pembelajaran kooperatif STAD hendaknya dapat dikembangkan dan ditingkatkan penggunanya dalam proses pembelajaran.

Kedua, penerapan model pembelajaran kooperatif tipe STAD dalam proses pembelajaran dimaksudkan untuk membiasakan siswa bekerja sama dengan kelompoknya, aktif dan antusias yang baik dalam pembelajaran, sedangkan sebaliknya pembelajaran dengan menggunakan model pembelajaran konvensional membuat siswa kurang dapat mengembangkan pola berfikirnya karena hayna guru yang aktif dalam proses pembelajaran. Implikasi nya adalah guru harus dapat memilih model pembelajaran yang sesuai dengan karakter peserta didik, salah satunya 
dengan menggunakan model pembelajaran kooperatif tipe STAD.

\section{SIMPULAN}

Berdasarkan hasil penelitian dan pembahasan dapat disimpulkan sebagai berikut.Terdapat perbedaan hasil belajar teknik dasar passing bola basket (chest pass dan overhead pass) antara siswa yang dibelajarkan menggunakan model pembelajaran kooperatif tipe Student Teams Achievement (STAD) dengan siswa yang dibelajarkan menggunakan model pembelajaran konvensional dimana rata-rata skor hasil belajar siswa di kelompok eksperimen lebih besar dari skor rata-rata siswa di kelompok kontrol.

Berdasarkan temuan diatas, dapat disimpulkan bahwa model pembelajaran kooperatif tipe STAD berpengaruh positif terhadap hasil belajar teknik dasar passing bola basket (chest pass dan overhead pass) siswa.

Berdasarkan hasil penelitian dan pembahasan, maka dapat diajukan beberapa saran untuk proses pembelajaran dan penelitian lebih lanjut sebagai berikut. 1. Bagi guru Pendidikan jasmani olahraga dan kesehatan (Penjasorke), model pembelajaran kooperatif tipe STAD dapat dijadikan salah satu alternatif pembelajaran yang dapat diterapkan di kelas.2. Penelitian ini dilaksanakan pada pokok bahasan teknik dasar passing bola basket di kelas XI SMA Karya Wisata Singaraja, sehingga untuk memperoleh bukti-bukti yang lebih umum dari penerapan model pembelajaran kooperatif tipe STAD diharapkan peneliti lain untuk mencoba pada pokok bahasan lain untuk mengetahui pengaruh penerapan model pembelajaran kooperatif tipe STAD dalam pembelajaran Penjasorkes secara lebih mendalam.3. Penelitian ini hanya mengukur ada atau tidaknya pengaruh dari model pembelajaran kooperatif tipe STAD terhadap hasil belajar teknik dasar passing bola basket (chets pass dan overhead pass) tanpa meneliti lebih jauh arah pengaruh yang diberikan. Di waktu mendatang dapat dilakukan suatu penelitian untuk meneliti sejauh mana arah pengaruh yang diberikan oleh model pembelajaran kooperatif tipe STAD terhadap hasil belajar siswa.

\section{DAFTAR PUSTAKA}

Ahriani, Faridha. (2013). Pengaruh model
pembelajaran kooperatif dan
gaya belajar terhadap hasil
belajar kimia peserta didik
kelas X SMK Negeri 2
BantaengTersediapada:pasca.
$\underline{\text { undiksha.ac.id/ejournal/index. }}$
$\underline{\text { php/jurnal pendas/article/view }}$
$\underline{768}$

Kanca, I Nyoman. 2010. Metodologi Penelitian Pengajaran Pendidikan Jasmani dan Olahraga. Singaraja : Universitas Pendidikan Ganesha

Sariyasa. (2013). Pengaruh Model Pembelajaran Kooperatif STAD Terhadap Hasil Belajar IPS dan Keterampilan Sosial pada Siswa Kelas $V$ SD Negeri 1 Joworawu Lombok Timur Tahun Pelajaran 2012/2013 Tersediapada: pasca.undiksha.ac.id/ejournal/i ndex.php/jurnal_pendas/article /view/768.

Subadi, T. 2011. Pengembangan Peningkatan Kualitas Guru Melalui Pelatihan Lesson Study Bagi Guru SD Eks Karesidenan Surakarta. Tersedia pada http://suaraguru.wordpress.co m/2011/01/16/pengembanganmodel-peningkatan-kualitasguru-melalui-pelatihan-lessonstudy-bagi-guru-sd-ekskaresidenan- surakarta/. 
Sudiarpa, I Komang. (2015). Pengaruh Model Pembelajaran Kooperatif STAD Terhadap Hasil Belajar IPA pada Siswa Kelas V SD No. 5 Songan Tahun Pelajaran 2013/2014 Tersedia pada: http: //ejournal.undiksha.ac.id/index .php/JJPGSD/article/view/590 $\underline{9}$

Sugiyono, 2008. Metode Penelitian Kuantitatif Kualitatif dan $R \& D$. Bandung: Alfabeta. 